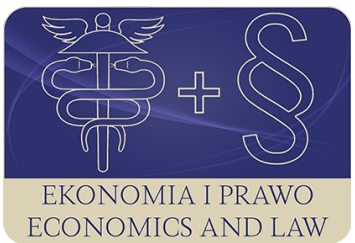

EKONOMIA I PRAWO. ECONOMICS AND LAW

Volume 20, Issue 1, March 2021

p-ISSN 1898-2255, e-ISSN 2392-1625

www.economicsandlaw.pl

EKONOMIA I PRAWO
ECONOMICS AND LAW

ORIGINAL ARTICLE

received 03.10.2020; revised 26.03.2021; accepted 31.03.2021

Citation: Lis, A., Bello, K., \& Górka, J. (2021). Albania as an object and a context of research in economic sciences: bibliometric analysis. Ekonomia i Prawo. Economics and Law, 20(1): 139-154. doi:10.12775/EiP.2021.009.

\title{
Albania as an object and a context of research in economic sciences: bibliometric analysis
}

\author{
ANDRZEJ LIS \\ corresponding author \\ Nicolaus Copernicus University in Torun, Faculty of Economic Sciences and Management, \\ Department of Business Excellence, ul. Gagarina 13a, 87-100 Toruń, Poland \\ ๑andrzejlis@umk.pl \\ orcid.org/0000-0003-4080-4137 \\ KRESHNIK BELLO \\ European University of Tirana, Department of Management and Marketing, Albania \\ 曰 kreshnik.bello@uet.edu.al \\ (D) orcid.org/0000-0002-5273-4693

\section{JOANNA GÓRKA} \\ Nicolaus Copernicus University in Torun, Faculty of Economic Sciences and Management, \\ Department of Econometrics and Statistics, Poland \\ ๑ joanna.gorka@umk.pl \\ D orcid.org/0000-0002-9959-5432
}

\begin{abstract}
Motivation: In recent years Albania has been an object of amassing research in many subject areas, including those related to economic sciences. Nevertheless, this growing scientific output has not been mapped from the bibliometric perspective. Thus, filling the identified gap in the body of knowledge is motivation for this study.

Aim: The aim of the paper is to map the conceptual structure of research output in economic sciences with the focus on Albania as an object or a context of scientific inquiry in order to identify and explore leading and emerging topics. The study is oriented to answering the following research questions: (1) What are the leading topics/streams of sci-
\end{abstract}


entific inquiry in the field? (2) What are the most up-to-date (emerging) topics/streams in the field?

Results: Analysing co-occurrence of high-frequency keywords of Scopus-indexed publications including phrase 'Albania' in their titles, keywords and abstracts leads to identification of seven thematic clusters within the research field: (1) Albania as a transition economy, (2) economic aspects of migration, (3) Western Balkans studies, (4) education and innovation, (5) regional case and comparative studies, (6) economic growth and development, and (7) democratic transition and European integration. Moreover, the analysis reveals the following up-to-date topics attracting recently increasing attention of the academia: European integration, cointegration, consumer preferences, monetary

policy, Western Balkans, higher education, performance, developing countries.

Keywords: Albania; bibliometrics; scientometrics; science mapping; co-word analysis; keywords co-occurrence analysis

JEL: 052

\section{Introduction}

Scientific inquiry is an activity of paramount importance for the rise of the knowledge-based society. Through conducting research academia contributes to producing new knowledge and development of the knowledge base. Scanning the resources of the Scopus database indicates that in recent years Albania has been an object of amassing research in many subject areas, including those related to economic sciences. In February 2019, Scopus comprised more than 5,500 publications mentioning Albania within their titles, keywords and abstracts. Among them there were 689 records categorized under the subject areas of Economics, Econometrics and Finance or Business, Management and Accounting.

Literature reviews are traditional approaches to analyse scientific output in a research field, and discuss its intellectual and conceptual structure (Tranfield et al., 2003). On the one hand literature reviews are characterized by thoroughness of analysis. Nevertheless, on the other hand, they have limited capacities to scan wide research fields of a large number of publications. Thus, for analysing large bodies of literature a macro approach based on bibliometric methodologies is recommended. Science mapping methods, which may be used for mapping various aspects of a research field include: co-authorship analysis, direct citation analysis, co-citation analysis, bibliographic coupling, and coword analysis (Klincewicz et al., 2012; Zupic \& Cater, 2015). Bibliometrics has becoming a more and more popular research approach in management and economics research. As of 28 March 2021, within Scopus defined subject areas of Economics, Econometric and Finance, and Business, Management and Accounting, we found 2,750 publications comprising the expression 'bibliometric' in their titles, keywords and abstracts (topic search). The majority of them have been published since 2017 i.e., 2017 - 263 items, 2018 - 306, $2019-411$, 2020 - 587. In the first quarter of 2021, 203 publications have been indexed, which allows to predict an annual output of about 800 items. 
In our paper we are interested in the analysis of the conceptual structure of research in economic sciences with the focus on Albania as an object or a context of study. So far, this aspect of the research field has not been mapped with bibliometric methods. To confirm this observation, as of 04 February 2019, we conducted the following query in the Scopus database: search for Topic (Title, Keywords, Abstracts): ('Albania') AND ('keyword analysis' OR 'co-occurrence analysis' OR 'bibliometric' or 'bibliometrics'); subject area: Economics, Econometrics and Finance OR Business, Management and Accounting; time span: unlimited. Nevertheless, no records meeting the aforementioned assumptions were found which may indicate the gap in the body of knowledge. Moreover, we found no publications providing a comprehensive systematic literature review of the research field.

Therefore, making an attempt to fill the identified gap, the aim of the paper is to map the conceptual structure of research within economic sciences with the focus on Albania as an object or a context of scientific inquiry in order to identify and explore leading and emerging topics. The study is oriented to answering the following research questions: (1) What are the leading topics/streams of scientific inquiry in the field? (2) What are the most up-to-date (emerging) topics/streams in the field?

The remaining body of the paper is structured into four parts. First of all, the research methodology and the sampling process for the bibliometric study are presented. Secondly, keywords co-occurrence analysis is conducted resulting in the clustering of keywords into leading topics/streams of research. Thirdly, the structure of identified clusters is studied. Finally, emerging topics/ streams of research within the field are enumerated and discussed.

\section{Method of study}

\subsection{Research sample}

Scopus was a source of bibliometric data for the research sampling process. The following search was completed on 09 February 2019: search for Topic (Title, Keywords, Abstracts): ('Albania'); subject area: Economics, Econometric and Finance OR Business, Management and Accounting; time span: unlimited.

The research sample consists of 689 records. 556 of them are indexed within the Economics, Econometrics and Finance subject area, 218 - in the Business, Management and Accounting area. The sample shares some publications with 16 other research areas, including: Social Sciences (391 items), Arts and $\mathrm{Hu}-$ manities (269), Energy (30), Agricultural and Biological Sciences (29), Environmental Science (21), Earth and Planetary Sciences (20), Engineering (19), Decision Sciences (12), Computer Sciences (10) and others. Articles make up a vast majority $(567,82.3 \%)$ of document types within the sample. They are 
followed by: book chapters (37, 5.4\%), business articles (31; 4.5\%), reviews (16; $2.3 \%)$, notes $(11 ; 1.6 \%)$. The share of other types of documents is marginal.

Certainly, the major bulk of papers $(325 ; 47.2 \%)$ was authored or co-authored by scholars representing Albanian research institutions. However, significant contributions are also made by researchers from institutions affiliated in other countries e.g. the United States (82; 11.9\%), the United Kingdom (62; $9.0 \%)$, Italy (49; 7.1\%), Greece (22; 3.2\%), Germany (18; 2.6\%), France (15; 2.2.\%), North Macedonia $(15 ; 2.2 \%)$, Spain $(15 ; 2.2 \%)$, the Netherlands (12; $1.7 \%)$ and Serbia (12; 1.7\%). The most productive research institutions contributing to the sample are: the University of Tirana (112 items; 16.2\%), Agricultural University of Tirana (30; 4.4.\%), Aleksander Moisiu University (26; 3.8\%), The World Bank (23; 3.3\%), Epoka University (11; 1.6\%), the University of Sussex $(8 ; 1.2 \%)$, University of Hawaii at Manoa $(7 ; 1.0 \%)$, the University of Kent (6; 0.9), the Sapienza University of Rome (6; 0.9\%); City College Thessaloniki (6; $0.9 \%)$. The most productive source titles contributing to the research sample include: Mediterranean Journal of Social Sciences (250 items; 36.3\%), Petroleum Economist (35; 5.1\%), Eastern European Economics (18; 2.6\%), Courrier des Pays de l'Est (12; 1.7\%), Post Communist Economies (12; 1.7\%), Europe Asia Studies (9; 1.3\%), New Medit (9; 1.3\%) and Economics of Transition (8; 1.2\%).

\subsection{Research methods and instruments}

Keywords co-occurrence analysis, a kind of co-word analysis (He, 1999), and systematic literature review (Czakon, 2011; Tranfield et al., 2003) were combined to achieve the aim of the study. Science mapping with the use of coword analysis followed the methodological recommendations provided by Zupic and Cater (2015). VOSviewer application (van Eck \& Waltman, 2010, 2014, 2018) was used to support mapping of keywords co-occurrence and clustering keywords. For creating the map, full counting co-occurrence analysis of all keywords was applied (cf. Perianes-Rodriguez et al., 2016). For the analysis, association strength method was chosen as an option for normalization of strength of the links between items. Default values were selected for attraction (2) and repulsion (0) parameters. The following values of parameters were applied for clustering: resolution parameter (related to the detail of clustering) -2 , minimum cluster size -5 . The function of merging small clusters was switched on. The status of research within identified emerging topics/streams was explored with the method of systematic literature review (Czakon, 2011). 


\section{Leading research themes}

\subsection{Identifying leading research themes}

Within the sample we identified 2,233 keywords. The top high-frequency keywords are: 'Albania' (196 occurrences), 'Europe' (30), 'economic growth' (27), 'Eurasia' (23), 'Southern Europe' (21), 'transitional economy' (19), 'transition' (14), 'Bulgaria' (13), 'education' (12), 'employment' (12), and 'Mecedonia' (12). The number of high-frequency keywords recommended for co-occurrence analysis, calculated in accordance with the formula recommended by Donohue (1974, as cited in Guo et al., 2017, p. 7) is 60, which means the minimum number of occurrences equal to 5 . However, the sample includes 70 keywords meeting this minimum co-occurrence requirement, which will be subject to further analysis. The map of keywords co-occurrence is presented in Figure $1^{1}$.

In VOSviewer maps, clusters do not overlap i.e. an item may belong to only one cluster. The higher prominence of items i.e. a higher number of occurrences the bigger size of the nodes and labels representing them in the map. The distance between the items represents the strength of their interrelatedness i.e. the closer they are located to each other, the stronger relationship between them is observed (van Eck \& Waltman, 2018).

Mapping of keywords co-occurrence points out seven clusters grouping economic sciences publications related to Albania as an object or a context of the study. Cluster analysis of high-frequency keywords is provided in Table 1.

\subsection{Exploring leading research themes}

Cluster 1 (marked in red in Figure 1) comprises 13 keywords mentioned in 223 publications. 'Albania' is the central node of the cluster and the whole map. 'Transition' and 'transitional economy' are two other expressions worth mentioning due to their prominence measured by the number of occurrences and centrality. Therefore, we label the cluster 'Albania as a transition economy'. 'Tirana' is another expression strongly linked with the aforementioned ones. Within the cluster, two main branches may be observed. The first of them deals with political and economic issues such as: 'election', 'corruption', 'monetary policy', 'fiscal policy', 'exchange rate' and 'inflation'. The second one is focused on 'privatization' and 'foreign direct investment'. Moreover, 'consumer preferences' is found to be a keyword standing alone at the frontier of the map.

Cluster 2 (marked in green in Figure 1) includes 13 keywords from 60 publications. Any central node can be hardly identified. However, many of the items are related to migration (e.g. 'emigration', 'internal migration', 'international migration') or economic aspects of it ('income distribution', 'living standard', 'migrants remittance', 'remittances'). That is why we assume that the clus-

${ }^{1}$ Available online at: http://dx.doi.org/10.12775/EiP.2021.009. 
ter is focused mainly on economic aspects of migration. Albania remains one of the countries with the lowest income in Europe. Poverty has forced many people since 1990 to migrate mainly toward Europe in search of a better life (Madani et al., 2013). Twenty years after the collapse of the harshest communist regime in Europe, the half of Albanians (1.4 million) lived abroad (King \& Vullnetari, 2012). Internal migration has also taken place on a massive scale.

Cluster 3 (marked in blue in Figure 1 ) is made by 11 keywords originating from 59 publications. A lot of articles of this cluster are concerned with analysis of South-Eastern Europe (SEE) countries or selected transition countries in Europe. International organizations classify the following countries in SEE (Western Balkans): Albania, Bosnia and Herzegovina, Croatia, North Macedonia, Montenegro and Serbia. Expressions such as 'Eurasia', 'Europe' and 'Southern Europe' are found to be the most often cited. Nevertheless, all the three occupy rather peripheral positions in the cluster's map. Keywords related to other geographical locations within the region (e.g. 'Balkans', 'Bosnia and Herzegovina', 'Croatia', 'Macedonia', 'Montenegro' and 'Serbia') are spatially represented in the left part of the map and are close to other countries subject to case and comparative studies categorized under Clusters 5 (Bulgaria, Romania) and 7 (Kosovo, Greece).

Cluster 4 (marked in yellow in Figure 1) consists of 11 keywords distributed over 65 publications. Three branches may be distinguished within the cluster. The first one includes the expressions 'national economy', 'transition economies', 'institutions' and 'entrepreneurship'. The second one is made by the keywords 'Eastern Europe', 'innovation' and 'education'. The last one comprises phrases 'developing countries', 'income', 'performance' and 'public sector'. Hardly any dominant theme may be observed within this cluster as it includes miscellany of issues in the context of a developing country/transition economy. Due to centrality of their positions we labelled the cluster after 'education and innovation'. Nevertheless, we are aware of the fact that such an operation may be flawed with overgeneralization.

Cluster 5 (marked in violet in Figure 1) comprises 9 keywords mentioned in 43 publications. 'Macedonia', 'Bulgaria' and 'Romania' are the most often cited keywords categorized within the cluster. The cluster shows many linkages with other case studies and comparative analyses related to the countries of the region classified within Clusters 3 and 7 . That is why we labelled the cluster as 'regional case and comparative studies'.

Cluster 6 (marked in light blue in Figure 1) includes 7 keywords from 59 publications. Its emphasis is placed on economic growth and development. Keywords 'economic growth', 'economic development' and 'employment' are found to be the central and most prominent items within the cluster. Important relationships are noticed between Cluster 5 and publications categorized under Clusters 2 (economic aspects of migrations), 3 (Western Balkans studies) and 5 (regional case and comparative studies). 
Cluster 7 (marked in orange in Figure 1) is made by 6 keywords from 33 publications. Within the cluster, two branches may be identified. The first one relates to keywords 'Greece' and 'Kosovo'. This branch shows numerous relationships with Western Balkans studies (Cluster 3) and the publications dealing with the issues of migrations (Cluster 2). The second branch of Cluster 7 is clearly distinguished from other thematic areas and focused on 'democracy', 'human right', 'integration' and 'European integration'. In consequence, we labeled the cluster as 'democratic transition and European integration'.

\section{Emerging research topics}

The overlay visualization of the VOSviewer application was used to identify the most up-to-date (emerging) topics within the sample. The findings from this analysis are presented in Figure $2^{2}$. The analysis reveals the following up-to-date topics attracting recently increasing attention of the academia: 'European integration', 'cointegration', 'consumer preferences', 'monetary policy', 'Western Balkans', 'higher education', 'performance', 'developing countries'.

The studies related to the European integration encompass a wide range of aspects including: democratization and political issues, human rights, regional development, education and media. Shehaj (2015) considers the challenges faced by Albania in its way to the European integration and the role of the EU to support democratization of the country. Sanxhaktari (2010) discusses the situation of Albania as a case of the importance of fundamental political criteria in the EU integration process, with the main focus given to human rights requirements. Marku (2015) investigates the role of the central and local governments for the regional development of the country, which is found to be important for the European integration process. Xhelilaj (2014) deals with the integration of Albanian education with the EU standards through analyzing the issues of students' achievements and participation of Albanians in PISA assessments. Georgieva et al. (2015) analyse the systems of media in Albania, Bulgaria, North Macedonia and Serbia discussing among others their integration into the European information space.

Albania serves as a case study for cointegration analysis of various macroeconomic variables. Kurtovic (2017) investigates the impact of the Albanian lek (ALL) depreciation on the country trade balance and confirms a long term cointegration between these two variables. Golitsis et al. (2018) analyze the effects of remittances and foreign direct investments on economic growth, gross fixed capital formation, and inflation in Albania. Turan and Gjergji (2014) study the cause-effect relationship between savings and economic growth. Their findings confirm the cointegration of these two variables. Kristo (2014) studies the contribution of the tourism industry to the GDP growth rate. Acaravci and Ozturk (2010) test the casual relationship between electricity consumption and economic growth in transition economies including Albania.

\footnotetext{
2 Available online at: http://dx.doi.org/10.12775/EiP.2021.009.
} 
The studies of Albanian consumer preferences are focused mainly on food and agricultural products. Zhllima et al. (2012) conduct the comprehensive analysis of changes in preferences of Albanian food consumers including such products as e.g. meat, fruits, vegetables, cereals. The other studies focus on a particular type of food. The units of analysis are e.g.: local products (Imami et al., 2015), cheese (Imami et al., 2016), yogurt (Zhllima et al., 2017), table olives (Zhllima et al., 2015), lamb meat (Dashi et al., 2013; Imami et al., 2011).

Among the papers related to monetary policy, Findreng (2014) investigates the synchronisation of some East European (including Albanian) and German economies to check whether they are ready for joining the European Monetary Union. Kola \& Liko (2011) study determinant factors of inflation in Albania. Imami et al. (2018) investigate the influence of political cycles on non-fiscal/ non-monetary variables (mining licensing). Naqellari explores the negative outcomes of privatization of commercial banks (Naqellari, 2013b) and restructuring of the banking sector in Albania (Naqellari, 2013a).

The publications focused on Western Balkans can be generally classified in two categories i.e. (l) these dealing with the issues of integration with the European Union including lessons, assessments and recommendations in this area, and (2) those using Albania and other Western Balkans countries as the context for case studies and other analyses. The first of the aforementioned categories is mostly focused on the macro level, including political and economic perspectives. Dabrowski and Myachenkova (2018) present efforts and challenges of Western Balkans countries in their way to accession to the European Union. Sokolova (2016) analyses, from the Russian perspective, the commitment and efforts of Western Balkans nations towards integration with Euro-Atlantic structures. Kostoska and Hristoski (2017) make an attempt to assess the competitiveness of the Western Balkans region in the context of aspirations to join the EU. Damiani and Uvalic (2014) identify lessons related to industrial policy and development in 'old' EU countries and use them to develop recommendations for Western Balkans economies. Within the frame of the second category, using econometric methods, Pere (2015) studies the role of good governance for the GDP growth rate in Western Balkans countries. Zhilla (2011) explores the role played by customary norms for the issues of organized crime and judicial corruption in Albania. Mendola and Carletto (2012) examine the role of migration in affecting the labor market opportunities of male and female household members left behind. Tenchov and Missopoulos (2010) use the cases of Albania, Kosovo and North Macedonia to study the criteria for assessing the suppliers in the pharmaceutical industry.

Within the stream of research focused on the issues of higher education, Treska and Canaj (2013) discuss achievements and challenges in reforming Albanian higher education in accordance with the Bologna standards. Dobi (2016) analyses the case of the European University of Tirana to illustrate the new approach to leadership, management and organization of a higher education institution operating in the Albanian context. Papadimitriou (2017) examines 
the efforts of Western Balkans universities to build-up their branding and images in the Internet. Guleker and Keci (2014) investigate the influence of class attendance on academic achievements.

Performance in both business and the public sector is another issue attracting increasing attention of researchers in recent years. Gerdoci et al. (2018) analyze relationships between business model design and company performance in the context of a developing country. Kellici et al. (2015) investigate how mobile technology influences organizational performance. Sinaj and Dumi (2015) study individual performance evaluation in the context of the public sector. Stillo (2011) investigates the importance of financial motivators for performance of Albanian public servants.

The cluster of publications dealing with the issue of 'developing countries' covers a variety of papers, which embed their research in the given context. They include the studies related both to management issues (e.g. strategic management, public management, project management, knowledge management, quality management) and economics. Already mentioned publication by Gerdoci et al. (2018) deals with business model design and company performance. Kromidha and Holloway (2011) study the contribution of international assistance to advancement of eGovernment in developing countries. Kromidha (2017, p. 1587) analyzes the case of "implementation of the electronic system of business registration in Albania" in order to understand "network politics in a multi-actor information system projects". Elezi and Bamber (2016) study knowledge transfer in an international company and its contribution to company performance as well as employee development and organizational culture change. Grazhdani et al. (2015) identify the dimensions of banking quality in the context of Albania as an example of a developing country. Devkota and Upadhyay (2015) study the influence of income and education on utilizing health care. Lumanaj and Hasi (2012) assess the public program of economic aid for the poor from the perspective beneficiaries and provide a set of recommendations to improve the program. Davis et al. (2009) use the case of Albania among other developing countries to analyze diversification of incomes in rural households.

\section{Conclusion}

The paper makes a contribution to the body of knowledge within the subject area of economic sciences through mapping the conceptual structure of research output focused on Albania as an object or a context of the study. The novelty and innovation of the study results from the fact that an operation of bibliometric mapping of the research field has never been completed before. Making an attempt to answer the first research question (What are the leading topics/ streams of scientific inquiry in the field?), we identified seven thematic clusters within the research field: (1) Albania as a transition economy, (2) economic aspects of migration, (3) Western Balkans studies, (4) education and innovation, (5) regional case and comparative studies, (6) economic growth and devel- 
opment, and (7) democratic transition and European integration. In response to the second research question (What are the most up-to-date (emerging) topics/streams in the field?), we found that recently the research in economic sciences related to the Albanian context has been focused on such aspects as: European integration, cointegration, consumer preferences, monetary policy, Western Balkans, higher education, performance, developing countries.

Summing up, limitations of the study should be made explicit. First of all, using the Scopus database as a source for research sampling process excluded publications not covered by this database. This should be considered as a shortage due to the bias of Scopus towards English language publications. In consequence, the survey aimed at mapping research focused on Albania as an object or a context did not take into account of some works published in Albanian language. We are aware of this weakness but we decided to concentrate on Scopus-indexed research output published in English to make it available for international scholars and induce the interest of non-Albanians in conducting research related to the Albanian context. Nevertheless, we strongly support and encourage the replication of the study based on the research sample comprised of publications issued in Albanian language. Secondly, the idea of the paper was to overview the research field and map it. In consequence, the study covers a wide range of topics and aspects and is not able to provide a detailed analysis of research status within identified leading/emerging streams of research. Therefore, we recommend to explore more thoroughly particular thematic clusters and research streams in separate studies. Thirdly, only one science mapping method, i.e. keywords co-occurrence analysis (a kind of coword analysis), was employed for mapping the conceptual structure of the field. Thus, triangulation of research with the use of other science mapping methods, e.g. direct citation analysis, co-citation analysis or bibliographic coupling, is recommended. Compare and contrast analysis of the conceptual structure of the field based on the findings from various science mapping methods seems to be an interesting line for further research.

Through mapping the conceptual structure of the research field focused on Albania as an object and a context of scientific inquiry, the study's contribution is first and foremost of theoretical character. Identification of leading themes and emerging topics indicates economic and management issues of the highest relevance in a country under the economic transition. Mapping the conceptual structure of the field may be also useful for scholars planning their research in the Albania's context to find inspiration for further studies. Last but not least, through collecting and disseminating knowledge about research on Albania conducted in economic sciences, the study may contribute to making it more recognized in the international scholar community, opening the opportunities for international collaboration. 


\section{References}

Acaravci, A., \& Ozturk, I. (2010). Electricity consumption-growth nexus: evidence from panel data for transition countries. Energy Economics, 32(3). doi:10.1016/j.eneco.2009.10.016.

Czakon, W. (2011). Metodyka systematycznego przeglądu literatury. Przegląd Organizacji, 3. doi:10.33141/po.2011.03.13.

Dabrowski, M., \& Myachenkova, Y. (2018). The Western Balkans: weak performance since the crisis. Acta Oeconomica, 68(S2). doi:10.1556/032.2018.68. S2.5.

Damiani, M., \& Uvalic, M. (2014). Industrial development in the EU: lessons for the future member states. Croatian Economic Survey, 16(1). doi:10.15179/ ces.16.1.1.

Dashi, E., Thoma, L., Kapaj, A., \& Guri, F. (2013). Butchers willingness to pay for packed lamb meat: case of Tirana butcher shops. Mediterranean Journal of Social Sciences, 4(9). doi:10.5901/mjss.2013.v4n9p554.

Davis, B., Winters, P., Reardon, T., \& Stamoulis, K. (2009). Rural nonfarm employment and farming: household-level linkages. Agricultural Economics, 40(2). doi:10.1111/j.1574-0862.2009.00374.x.

Devkota, S., \& Upadhyay, M. (2015). How do income and education affect health inequality: evidence from four developing countries. Applied Economics, 47(52). doi:10.1080/00036846.2015.1054069.

Dobi, T. (2016). Major changes to leadership, management, and organizational structure: the case of the European University of Tirana. The International Journal of Knowledge, Culture, and Change Management: Annual Review, 11(6). doi:10.18848/1447-9524/cgp/vlli06/50214.

Donohue, J.C. (1974). Understanding scientific literature: a bibliometric approach. Cambridge: MIT Press.

Elezi, E., \& Bamber, C. (2016). Investigating knowledge management in emerging markets: an Albanian case example. International Journal of Knowledge Management Studies, 7(3/4). doi:10.1504/IJKMS.2016.082341.

Findreng, J.H. (2014). Relative purchasing power parity and the European monetary union: evidence from Eastern Europe. Economics \& Sociology, 7(1). doi:10.14254/2071-789X.2014/7-1/3.

Georgieva, E.S., Danilova, Y.S., Bykov, A.Y., Sergeevna, A.S., \& Labush, N.S. (2015). Media systems of South-Eastern Europe in the condition of democratic transition: the example of Albania, Bulgaria, Macedonia and Serbia. International Review of Management and Marketing, 5(1S).

Gerdoci, B., Bortoluzzi, G., \& Dibra, S. (2018). Business model design and firm performance: evidence of interactive effects from a developing economy. European Journal of Innovation Management, 21(2). doi:10.1108/ EJIM-02-2017-0012. 
Golitsis, P., Avdiu, K., \& Szamosi, L.T. (2018). Remittances and FDI effects on economic growth: a VECM and GIRFs for the case of Albania. Journal of East-West Business, 24(3). doi:10.1080/10669868.2018.1435432.

Grazhdani, S., Vërçuni, A., \& Merollari, K. (2015). Bank service quality dimensions in developing and transition economies: the case of Albania. Mediterranean Journal of Social Sciences, 6(4). doi:10.5901/mjss.2015.v6n4p340.

Guleker, R., \& Keci, J. (2014). The effect of attendance on academic performance. Mediterranean Journal of Social Sciences, 5(23). doi:10.5901/mjss.2014. v5n23p961.

Guo, D., Chen, H., Long, R., Lu, H., \& Long, Q. (2017). A co-word analysis of organizational constraints for maintaining sustainability. Sustainability, 9(11). doi:10.3390/su9101928.

He, Q. (1999). Knowledge discovery through co-word analysis. Library Trends, 48(1).

Imami, D., Chan-Halbrendt, C., Zhang, Q., \& Zhllima, E. (2011). Conjoint analysis of consumer preferences for lamb meat in central and southwest urban Albania. International Food and Agribusiness Management Review, 14(3).

Imami, D., Lami, E., \& Uberti, L. J. (2018). Election cycles in mining licensing: theory and evidence from Albania. Post-Communist Economies, 30(1). doi:10. 1080/14631377.2017.1361692.

Imami, D., Skreli, E., Zhllima, E., Canavari, M., Chan, C., \& Cela, A. (2016). Analysis of consumers' preferences for typical local cheese in Albania applying conjoint analysis. New Medit, 15(3).

Imami, D., Skreli, E., Zhllima, E., Cela, A., \& Sokoli, O. (2015). Consumer preferences for typical local products in Albania. Economia Agro-Alimentare, 17(3). doi:10.3280/ECAG2015-003002.

Kellici, E., Baholli, I., \& Sharko, A. D. (2015). Increasing organization's overall performance through mobile technology: Albania case study. Mediterranean Journal of Social Sciences, 6(1). doi:10.5901/mjss.2015.v6nlp368.

King, R., \& Vullnetari, J. (2012). A population on the move: migration and gender relations in Albania. Cambridge Journal of Regions, Economy and Society, 5(2). doi:10.1093/cjres/rss004.

Klincewicz, K., Żemigała, M., \& Mijal, M. (2012). Bibliometria w zarządzaniu technologiami i badaniami naukowymi. Retrieved 29.03.2021 from https:// kpbc.umk.pl.

Kola, T., \& Liko, E. (2011). Price development in Albania. Periodica Polytechnica Social and Management Sciences, 19(1). doi:10.3311/pp.so.2011-1.01.

Kostoska, O., \& Hristoski, I. (2017). ICTs and innovation for competitiveness: evidence for Western Balkans vis-à-vis the European Union. Zbornik Radova Ekonomskog Fakultet Au Rijeci, 35(2). doi:10.18045/zbefri.2017.2.487.

Kristo, J. (2014). Evaluating the tourism-led economic growth hypothesis in a developing country: the case of Albania. Mediterranean Journal of Social Sciences, 5(8). doi:10.5901/mjss.2014.v5n8p39. 
Kromidha, E. (2017). Transitions of power in multi-actor information system projects. International Journal of Project Management, 35(8). doi:10.1016/j. ijproman.2017.08.010.

Kromidha, E., \& Holloway, R. (2011). International assistance relationship to eGovernment development and benchmarking. In M. Klun, \& T. Jukić (Eds.), The proceedings of the llth European Conference on eGovernment. Reading: Academic Publishing Limited.

Kurtović, S. (2017). The effect of depreciation of the exchange rate on the trade balance of Albania. Review of Economic Perspectives, 17(2). doi:10.1515/ revecp-2017-0007.

Lumanaj, B., \& Hasi, S. (2012). Evaluating low income families' self perception of the economic aid program: the Albanian case. Mediterranean Journal of Social Sciences, 3(2). doi:10.5901/mjss.2012.v3n2.73.

Madani, F., Muharremi, O., \& Pelari, E. (2013). The effect remittances have on the living standards of Albanians and on country's GDP. Mediterranean Journal of Social Sciences, 4(10). doi:10.5901/mjss.2013.v4nl0p415.

Marku, A. (2015). The role of central and regional government in the regional development of Albania. Mediterranean Journal of Social Sciences, 6(2S2). doi:10.5901/mjss.2015.v6n2s2p49.

Mendola, M., \& Carletto, C. (2012). Migration and gender differences in the home labour market: evidence from Albania. Labour Economics, 19(6). doi:10.1016/j.labeco.2012.08.009.

Naqellari, A. (2013a). The negative consequences of the restructuring of the Albanian banking system since the 90s. Mediterranean Journal of Social Sciences, 4(6). doi:10.5901/mjss.2013.v4n6p435.

Naqellari, A. (2013b). Total privatization of banks: is it the right or the wrong choice. Mediterranean Journal of Social Sciences, 4(9). doi:10.5901/mjss.2013. v4n9p343.

Papadimitriou, A. (2017). Using a mixed methods approach to examine the (re)imaging of higher education institutions in the Western Balkans. In A. Papadimitriou (Ed.), Competition in higher education branding and marketing: national and global perspectives. Cham: Palgrave Macmillan. doi:10.1007/978-3-319-58527-7_5.

Pere, E. (2015). The impact of good governance in the economic development of Western Balkan countries. European Journal of Government and Economics, 4(1).

Perianes-Rodriguez, A., Waltman, L., \& van Eck, N.J. (2016). Constructing bibliometric networks: a comparison between full and fractional counting. Journal of Informetrics, 10(4). doi:10.1016/J.JOI.2016.10.006.

Sanxhaktari, V. (2010). The respect for fundamental in EU as an eligibility for the candidate countries: the Albania case. Mediterranean Journal of Social Sciences, 5(20).

Shehaj, E. (2015). Challenges of Albania towards the European Integration. Mediterranean Journal of Social Sciences, 6. doi:10.5901/mjss.2015.v6n4s2p571. 
Sinaj, Z., \& Dumi, A.R. (2015). Evaluation, a challenge for successful management, performance and motivation of the public administration empirical analysis in front of theory-cal analysis. Mediterranean Journal of Social Sciences, 6(1). doi:10.5901/mjss.2015.v6nlp261.

Sokolova, P.S. (2016). Euro-Atlantic commitment of Western Balkans. World Economy and International Relations, 60(7). doi:10.20542/0131-2227-2016-60-7-37-47.

Stillo, S. (2011). The role of salary as a motivating strategy for increasing the quality and the stability of the public administration in Albania. International Journal of Economic Perspectives, 5(1).

Tenchov, G., \& Missopoulos, F.S. (2010). Key performance indicators for the assessment of suppliers in the retail of pharmaceutical products: comparative research in the region of Western Balkans (Albania, Macedonia and Kosovo). In SCMIS 2010: Proceedings of 2010 8th International Conference on Supply Chain Management and Information Systems: Logistics Systems and Engineering. Hing Kong: IEEE.

Tranfield, D., Denyer, D., \& Smart, P. (2003). Towards a methodology for developing evidence-informed management knowledge by means of systematic review. British Journal of Management, 14(3). doi:10.1111/1467-8551.00375.

Treska, T., \& Canaj, E. (2013). Albanian "Bologna": how close/far is Albanian higher education to European standards. Mediterranean Journal of Social Sciences, 4(10). doi:10.5901/mjss.2013.v4n10p666.

Turan, G., \& Gjergii, O. (2014). What is the impact of savings on growth: the case of a small open economy (Albania). Mediterranean Journal of Social Sciences, 5(13S). doi:10.5901/mjss.2014.v5nl3p360.

van Eck, N.J., \& Waltman, L. (2010). Software survey: VOSviewer, a computer program for bibliometric mapping. Scientometrics, 84(2). doi:10.1007/ sl1192-009-0146-3.

van Eck, N.J., \& Waltman, L. (2014). Visualizing bibliometric networks. In Y. Ding, R. Rousseau, \& D. Wolfram (Eds.), Measuring scholarly impact: methods and practice. Cham: Springer. doi:10.1007/978-3-319-10377-8_13.

van Eck, N.J., \& Waltman, L. (2018). VOSviewer manual. Retrieved 29.03.2021 from https://www.vosviewer.com.

Xhelilaj, L. (2014). The importance of 15 years old students' academic achievement and the participation of Albanian students in the PISA assessment. Mediterranean Journal of Social Sciences, 5(13S). doi:10.5901/mjss.2014. v5nl3p509.

Zhilla, F. (2011). Organised crime and judicial corruption in the Western Balkans. Journal of Financial Crime, 18(4). doi:10.1108/13590791111173713.

Zhllima, E., Chan-Halbrendt, C., Merkaj, E., Imami, D., Vercuni, A., \& Qinami, I. (2015). Analysis of consumer preferences for table olives: the case of Albanian urban consumers. Journal of Food Products Marketing, 21(5). doi:10.1080/10454446.2013.807407. 
Zhllima, E., Imami, D., \& Merkaj, E. (2012). Food consumer trends in post socialist countries: the case of Albania. Economia Agro-Alimentare, 14(3). doi:10.3280/ECAG2012-003007.

Zhllima, E., Imami, D., Merkaj, E., Qinami, I., \& Nesturi, E. (2017). Consumer preferences for yogurt in Albania. Economia Agro-Alimentare, 19(2). doi:10.3280/ECAG2017-002002.

Zupic, I., \& Cater, T. (2015). Bibliometric methods in management and organization. OrganizationalResearch Methods, 18(3). doi:10.1177/1094428114562629.

\section{Acknowledgements}

Author contributions: authors have given an approval to the final version of the article. Authors contributed to this work as follows: A.L. developed the concept and designed the study, A.L. collected the data, A.L., K.B. and J.G. analysed and interpreted the data, A.L. prepared draft of article, A.L. revised the article critically for important intellectual content.

Funding: this research was funded with statutory research budget by the Faculty of Economic Sciences and Management, Nicolaus Copernicus University in Torun, Poland.

Note: the results of this study were presented at the scientific conference Albanian Study Days VI/2019, The knowledge society: diagnostics and prognoses (April 12-13, 2019, Tirana, Albania). 


\section{Appendix}

\section{Table 1.}

\section{Clusters of high-frequency keywords}

\begin{tabular}{|c|c|c|c|}
\hline Symbol/color & Items $(\mathrm{N})$ & High-frequency keywords (N) & Issue \\
\hline $\mathrm{Cl} /$ red & 13 & $\begin{array}{l}\text { Albania (196), consumer preferences (7), corruption (11), election } \\
\text { (5), exchange rate (6), fiscal policy (5), foreign direct investment } \\
\text { (6), inflation (7), monetary policy (5), privatization (5), Tirana (6), } \\
\text { transition (14), transitional economy (19) }\end{array}$ & $\begin{array}{l}\text { Albania as } \\
\text { a transition } \\
\text { economy }\end{array}$ \\
\hline $\mathrm{C} 2$ /green & 13 & $\begin{array}{l}\text { development (5), emigration (6), gender (5), higher education (5), } \\
\text { income distribution (6), internal migration (5), international mi- } \\
\text { gration (9), living standard (7), migrants remittance (7), migration } \\
\text { (10), poverty (7), remittances (11), Western Balkans (9) }\end{array}$ & $\begin{array}{l}\text { economic } \\
\text { aspects of mi- } \\
\text { gration }\end{array}$ \\
\hline C3/blue & 11 & $\begin{array}{l}\text { Balkans (5), Bosnia and Herzegovina (8), Croatia (8), Eurasia } \\
\text { (23), Europe (30), European Union (10), international trade (5), } \\
\text { Macedonia (Southern Europe) (12), Montenegro (5), Serbia (8), } \\
\text { Southern Europe (21) }\end{array}$ & $\begin{array}{l}\text { Western Bal- } \\
\text { kans studies }\end{array}$ \\
\hline C4/yellow & 11 & $\begin{array}{l}\text { developing countries (8), Eastern Europe (9), education (12) } \\
\text { entrepreneurship (6), income (6), innovation (8), institutions } \\
\text { (5), national economy (6), performance (5), public sector (6), } \\
\text { transition economies (9) }\end{array}$ & $\begin{array}{l}\text { education } \\
\text { and innovation }\end{array}$ \\
\hline C5/violet & 9 & $\begin{array}{l}\text { Bulgaria (13), cointegration (5), economics (6), energy policy (5), } \\
\text { gross domestic product (5), Macedonia (12), market transition (7), } \\
\text { panel data (5), Romania (8) }\end{array}$ & $\begin{array}{l}\text { regional case } \\
\text { and comparative } \\
\text { studies }\end{array}$ \\
\hline C6/light blue & 7 & $\begin{array}{l}\text { econometrics (5), economic development (9), economic growth } \\
\text { (27), employment (12), investment (8), post-communism (8), } \\
\text { tourism (6) }\end{array}$ & $\begin{array}{l}\text { economic } \\
\text { growth and de- } \\
\text { velopment }\end{array}$ \\
\hline C7/orange & 6 & $\begin{array}{l}\text { democracy (5), European integration (5), Greece (10), human } \\
\text { rights (6), integration (6), Kosovo (6) }\end{array}$ & $\begin{array}{l}\text { democratic } \\
\text { transition } \\
\text { and European } \\
\text { integration }\end{array}$ \\
\hline
\end{tabular}

Source: own study based on data retrieved from the Scopus database as of 09 February 2019 and analysed with the use of VOSviewer. 